\title{
Resolving Disputes in China: New and Sometimes Unpredictable Developments
}

\author{
Jingzhou Tao and Mariana Zhong*
}

\begin{abstract}
China has been continuously making progress to improve its arbitration environment over the past several years. In the context of the Belt and Road Initiative (the BRI), the Chinese government expressly called for judicial support for alternative dispute resolution in China, including international arbitration. In response, the Supreme People's Court of China (SPC) issued several judicial documents by the end of 2017 in order to standardize and improve Chinese judiciaries' review of arbitration-related matters. Furthermore, innovative measures were taken with respect to China's Free Trade Zones (FTz) concerning redefinition of foreign-related factors, which had an impact on whether foreign-invested enterprises in China could submit their disputes to arbitration abroad, and under what circumstances to permit ad hoc arbitration in China. Various Chinese arbitration institutions have also updated their arbitration service.

The establishment of the China International Commercial Court (the CICC) is also a notable development as it seeks to integrate and streamline the mechanisms of litigation, arbitration and mediation. It also features such innovations as an expert committee, relaxed rules on evidence and language use. Admittedly, the CICC is still in its new-born stage and many operational rules are yet to be designed and applied. Still, parties to international commercial disputes are already eager to test this mechanism and take advantage of the accessibility to the SPC via the CICC system.
\end{abstract}

* Jingzhou Tao, managing partner of Dechert LLP China, member of the International Advisory Board of HKIAC and the Advisory Committee of CIETAC, listed arbitrator of several international and Chinese arbitration institutions including ICC, SIAC, HKIAC, CIETAC, BAC, SHIAC, SCIA, etc., member of International Commercial Expert Committee of Chinese Supreme Court, specially invited Professor of Law for the International Arbitration Program at Tsinghua University School of Law, Jingzhou.tao@dechert.com; Mariana Zhong, national partner of Dechert LLP, specializing in dispute resolution matters, in particular, international arbitration seated both in China and overseas, admitted in New York State and also passed the PRC bar, Mariana.zhong@dechert.com.

(C) ASIAN INFRASTRUCTURE INVESTMENT BANK (AIIB), 2019 | DOI:10.1163/9789004407411_006

This is an open access chapter distributed under the terms of the CC-BY-NC 4.0 License. 


\section{Introduction}

Resolving disputes in China has long been an important and meaningful proposition for international business and legal communities, especially for those who, or whose clients, have existing or future business in China or with Chinese companies. This proposition becomes even more significant and urgent following China's BRI announced in 2013, which unleashed billions of US dollars-worth of Chinese capital into around 65 countries along the Belt and Road'1 via Chinese outbound investments and foreign trade activities.

Statistics show that, among the foreign-related contracts signed by Chinese enterprises, more than $90 \%$ of the dispute settlement methods were arbitration. $^{2}$ This strongly proves that international commercial arbitration is the preferred way of resolving cross-border disputes between Chinese and foreign parties, compared with lawsuits before national courts. Arbitration enjoys several advantages over traditional litigation, and the most notable one is the enforceability of foreign arbitral awards in member countries of the ' 1958 Convention on the Recognition and Enforcement of Foreign Arbitral Awards' (the New York Convention), ${ }^{3}$ to which China is a member State.

In implementing the BRI, the Chinese Government also called for judicial support in terms of providing credible, efficient and effective Alternative Dispute Resolution (ADR) mechanisms for international disputes, with the particular intention to build China into an attractive seat for international disputes resolution. ${ }^{4}$

Against such backdrop, the SPC was possessed of a mandate and issued several judicial interpretations ${ }^{5}$ relating to Chinese courts' review of arbitrationrelated matters by the end of 2017, and further established the CICC in June 2018, which aims at resolving international commercial disputes through a 'one-stop platform' combining mechanisms of litigation, arbitration and mediation. The CICC is designed in order to create a transparent legal environment

1 Lau, 3 September 2017.

2 He, 19 September 2016.

3 The New York Convention. The New York Convention is currently the most important international convention for the recognition and enforcement of arbitral awards. As of now, the State party has reached 159 countries and regions and it has a positive and important position in the field of international commercial arbitration. In the context of BRI, the special role of the New York Convention is more prominent, which plays an irreplaceable role in promoting the implementation of arbitral awards between States Parties, and is conducive to the building of international rule of law.

4 H Shen, 21 November 2018, 7.

5 See Section 1.1 for details. 
and a credible (and additional) dispute resolution option that serves the construction of BRI.

In addition, leading Chinese arbitration institutions, such as the China International Economic and Trade Commission (CIETAC), the Beijing Arbitration Commission (BAC) and the Shenzhen Court of International Arbitration (SCIA), have all demonstrated their enthusiasm in developing and upgrading their institutional services, expanding their presence and attracting more international users, through for example, issuing new or revised arbitration rules that seek to align with prevailing international practices, and establishing cooperation with foreign or international arbitration institutions. ${ }^{6}$

Following this introduction, this chapter will briefly describe the several judicial interpretations issued by the SPC relating to arbitration (Section 2), the noticeable developments with Chinese arbitration institutions in the context of BRI (Section 3). This chapter will also briefly draw the picture of the CICC's establishment, underline its innovative features and lingering issues thereof (Section 4) and reaches a conclusion (Section 5).

There have been many criticisms against the deficiencies of the 'Arbitration Law of the People's Republic of China' (China's Arbitration Law) ${ }^{7}$ from both China and abroad. ${ }^{8}$ Comparison with prevailing international arbitration practice as embodied by the 'UnCITRAL Model Law on International Commercial Arbitration' (Unitral Model Law), renders China's Arbitration Law's obsolete character more prominent, and the voices calling for revision thereof based on the UNITRAL Model Law can well be heard from both arbitration communities and arbitration users. ${ }^{9}$ However, it turned out to be rather difficult for a formal legislative revision to actually take place.

\subsection{More Solid Judicial Supports from the Supreme People's Court}

In light of the difficulties of amending China's Arbitration Law, the SPC had to undertake the pioneering role and, according to the SPC itself, it has been exploring means to improve China's judicial environment within (and testing the boundaries of) the existing legal framework set by the China's Arbitration Law.

6 See Section 2 for details.

7 China's Arbitration Law.

8 Wang and Hilmer 2006; Fan 2008.

9 Liu and Lin 2018. 
The SPC has actually issued a series of judicial interpretations in 2017, in answering the State's call for judicial supports to BRI. These judicial documents include, for example,

- the 'Provisions of the Supreme People's Court on Application for Approval of Arbitration Cases that are Subject to Judicial Review' (the Provisions on Application for Approval); ${ }^{10}$

- the 'Provisions of the Supreme People's Court on Certain Issues related to the Conduct of Judicial Review of Arbitration Cases' (the Provisions on Conduct of Judicial Review), ${ }^{11}$ regulating and unifying Chinese courts' review of parties' applications pertaining to the domestic arbitrations and foreignrelated arbitrations;

- the 'Notice concerning Certain Issues regarding Centralized Administration of Judicial Review of Arbitration Cases' (the Notice of Centralized Judicial Review), ${ }^{12}$ unifying the internal frameworks and procedures for courts' judicial review of arbitration together with the aforementioned two judicial interpretations; and

- the 'Provisions on Certain Issues relating to People's Courts' Handling of Enforcement Cases of Arbitral Awards' (the Provisions on Handling of Enforcement Cases), ${ }^{13}$ notably entitling outsiders who are not parties to the case, to apply for non-enforcement of arbitral awards under certain conditions such as falsified arbitration, which stresses protection of outsiders' interests and is the first judicial pronouncement that clearly touches upon the regulation of falsified arbitration.

With the four judicial documents issued in 2017, the SPC, acting as the locomotive' for China's arbitration development, carefully refines and enhances the Chinese arbitration legal system, which may not be free from problems, but still, the judicial efforts towards a more arbitration-friendly environment are notable.

\subsection{Specific Developments in Free Trade Zone}

Another way of introducing pioneering developments is through pilot programs in Free Trade Zones (the FTZ) ${ }^{14}$ based upon the SPC's 'Opinions on

\footnotetext{
10 SPC, The Provisions on Application for Approval 2017.

11 SPC, The Provisions on Conduct of Judicial Review 2017.

12 SPC, The Notice concerning Centralized Administration of Judicial Review 2017.

13 SPC, The Provisions on Handling of Enforcement Cases 2018.

14 In July 2013, the State Council of China decided to establish the China (Shanghai) Pilot Free Trade Zone. In December 2014, the State Council decided to establish the China (Guangdong) Pilot Free Trade Zone, the China (Tianjin) Free Trade Zone, and the China (Fujian) Free Trade Zone. At the end of 2016, the State Council decided to establish seven
} 
Providing Judicial Safeguards for the Construction of Pilot Free Trade Zones' (the FTZ Opinions), ${ }^{15}$ which adopted an encouraging attitude towards arbitration in FTZ and made major breakthroughs as to application of the China's Arbitration Law in FTZ.

\subsubsection{Redefinition of Foreign-related Factors}

Previously, under China's legal framework, parties to a dispute that has no foreign-related factors are not allowed to submit their dispute to arbitration abroad. The legal definition of 'foreign-related factors' can be found in Article 1 of the 'Interpretations of the Supreme People's Court on Several Issues concerning Application of the Law of the People's Republic of China on Choice of Law for Foreign-Related Civil Relationships'.16 As such, parties of foreigninvested enterprises (the FIEs) in China, which have always been considered as Chinese legal persons, are not able to opt for foreign arbitration due to lack of 'foreign-related factors' in their identities.

The first breakthrough came in November 2015 in the case Siemens International Trade (Shanghai) Co., Ltd. v. Shanghai Golden Landmark Co., Ltd. (Siemens $v$. Golden Landmark), ${ }^{17}$ where the Shanghai First Intermediate People's Court made an expansive interpretation of 'foreign-related factors' and ruled that 'foreign-related factors'; can be found where, inter alia, firstly, both the applicant and the respondent are wholly foreign-owned enterprises (WFOEs) registered in a FTZ; and second, the performance characteristics of the contract bear foreign-related factors.

Although China is a civil law country where there is no binding effect of case precedents, the judicial attitude towards a more expansive interpretation

new free trade pilot zones in Liaoning Province, Zhejiang Province, Henan Province, Hubei Province, Chongqing City, Sichuan Province and Shaanxi Province.

15 SPC, The FTZ Opinions 2016.

16 SPC, Choice of Law for Foreign-Related Civil Relationships 2012, art 1. It provides, 'Where a civil relationship falls under any of the following circumstances, the people's court may determine it as foreign-related civil relationship: 1. where either party or both parties are foreign citizens, foreign legal persons or other organizations or stateless persons; 2. where the habitual residence of either party or both parties is located outside the territory of the People's Republic of China; 3 . where the subject matter is outside the territory of the People's Republic of China; 4. where the legal fact that leads to establishment, change or termination of civil relationship happens outside the territory of the People's Republic of China; or 5 . other circumstances under which the civil relationship may be determined as foreign-related civil relationship'.

17 Shanghai Intermediate Court No 1, Siemens v. Golden Landmark 2013. As one of the 'Top Ten Cases of China's Arbitration in 2015', this case has a very significant impact, and it has been regarded by many insiders as a benchmark for relaxing the 'foreign-related factors' review standards in China's foreign-related judicial trials. See Tang 2017. 
of 'foreign-related factors' concerning FIEs operating in FTZs, was soon captured and restated in the SPC's FTZ Opinions. Specifically, Article 9(1) of the FTZ Opinions ${ }^{18}$ provides that as long as the parties are WFOEs registered in a FTZ, the commercial disputes thereof could be identified as having foreignrelated factors, and thus can be directly submitted to overseas arbitration without even considering whether the contract performance characteristics have foreign-related factors.

Notably, the expansive and encouraging approach adopted in Article 9(1) is very meaningful for foreign investors who operate through FIEs in China. ${ }^{19}$ In the meantime, such permission only applies to WFOEs registered in FTZ, and is not available to other forms of FIEs such as joint ventures or cooperative enterprises.

Article 9(2) of the FTz Opinions ${ }^{20}$ further expands the scope of disputes that can be submitted to foreign arbitration, by applying the doctrine of estoppel, ${ }^{21}$ to disputes where one or two parties are FIEs and one or two parties are registered in FTZ.

\subsubsection{Conditional Permission of Ad Hoc Arbitrations}

Ad hoc arbitration is not allowed in China due to limitations under Article 16 and Article 18 of China's Arbitration Law, ${ }^{22}$ which provide that parties to an

18 SPC, The FTZ Opinions 2016, art 9(1). It provides, 'Where two wholly foreign-owned enterprises registered in FTZ agree that any commercial dispute shall be submitted to arbitration out of China, the relevant arbitration agreement shall not be determined to be null and void for the reason that their dispute has no foreign-related factors'.

19 Prusinowska 2017.

20 SPC, The FTZ Opinions 2016, art 9(2). It provides, 'Where two foreign-funded enterprises, either or both registered in FTZ, has agreed that any commercial dispute shall be submitted to arbitration out of China, when a dispute takes place, a party submits the dispute to arbitration out of China, and when the relevant arbitral award is made, the party refuses to admit, accept or enforce the award on the grounds that the arbitration agreement is invalid, the people's court shall not uphold it; and where the other party holds no objection to the force of the arbitration agreement in the arbitration proceedings, but when relevant award is made, claims the nullity of the arbitration agreement for the reason that relevant dispute has no foreign-related factors, and therefore refuses to admit, accept or enforce the award, the people's court shall not uphold it'.

21 Black's Law Dictionary defines estoppel as a 'bar or impediment raised by the law, which precludes a man from alleging or from denying a certain fact or state of facts, in consequence of his previous allegation or denial or conduct or admission, or in consequence of a final adjudication of the matter in a court of law'.

22 China's Arbitration Law, arts 16 and 18. Art 16 stipulates that, 'An arbitration agreement shall include arbitration clauses stipulated in the contract and agreements of submission to arbitration that are concluded in other written forms before or after disputes arise. An arbitration agreement shall contain the following particulars: (1) an expression of 
arbitration agreement must clearly designate a selected arbitration commission in order to render the arbitration agreement valid. Such attitude has been consistently embraced by domestic courts of different levels in their judicial practice. $^{23}$

As a breakthrough, Article 9(3) of the FTZ Opinions opens a window and makes it possible for ad hoc arbitration to take place in China, although under several rather vague conditions. Article 9 (s) reads as follows,

If two enterprises registered in FTZ agree that relevant disputes shall be submitted to arbitration at a specific place in Chinese mainland, according to specific arbitration rules, or by specific personnel, ${ }^{24}$ the arbitration agreement may be determined as valid. If the people's court holds that the arbitration agreement is null and void, it shall request the court at the next higher level for review. If the superior court consents to the opinions of the subordinate court, the former shall report its review opinions to the Supreme People's Court level by level, and render a ruling after the Supreme People's Court makes a reply.

The above rule can be read to the effect that ad hoc arbitration agreements are valid if (i) both the parties are registered in FTZ; and (ii) the agreement provides for a specific place in Chinese mainland, specific arbitration rules, and specific arbitrators (the so-called, 'Three Specific Conditions').

In the meantime, a reasonable interpretation is that, even where the vague conditions are present, the Chinese courts still enjoy the discretion to decide on the validity of such ad hoc arbitration agreement because 'the arbitration agreement may be determined as valid' (emphasis added). Where a court decides that such an ad hoc arbitration agreement is invalid, the Prior-reporting Mechanism, which essentially requires higher level courts' review of a matter before a final decision can be made, shall come into play, so as to ensure that

intention to apply for arbitration; (2) matters for arbitration; and (3) a designated arbitration commission'; art 18 stipulates that, 'If an arbitration agreement contains no or unclear provisions concerning the matters for arbitration or the arbitration commission, the parties may reach a supplementary agreement. If no such supplementary agreement can be reached, the arbitration agreement shall be null and void'.

23 Beijing Higher Court, Validity of an Arbitration Agreement and Cancellation of an Arbitral Award 1999. art 10. It states in the answer to the question that whether the ad hoc arbitration agreed by the parties in the arbitration agreement is valid or not that the ad hoc arbitration shall be deemed as invalid; Jiangsu Higher Court, Judicial Review of Arbitration Cases 2010, art 18. It stipulates that, 'If the parties agree to conduct ad hoc arbitration within the territory of China, the arbitration agreement shall be invalid'. 
the local courts' interpretations (over the validity of ad hoc arbitration agreements) are consistent.

On such basis, the first set of ad hoc arbitration rules in China, the 'Ad Hoc Arbitration Rules of the Hengqin Free Trade Zone', ${ }^{25}$ officially came into being on 23 March 2017, marking the actual arrival of ad hoc arbitration in the mainland China.

It is of course an encouraging signal for ad hoc arbitration to make its debut in China, despite being limited in scope. In practice, there remain many issues to be resolved relating to the operation of ad hoc arbitrations in China. For instance, how to define the Three Specific Conditions and whether they have to be met simultaneously? How to integrate ad hoc arbitration with the existing China's Arbitration Law? Under China's Arbitration Law, it essentially requires heavy involvement of arbitration institutions in many aspects of the proceeding, such as appointment of arbitrators and application of interim measures. Furthermore, does the ad hoc arbitration only apply to domestic disputes, or to foreign-related disputes as well? Do the arbitrators of the ad hoc arbitral tribunal have to also meet the requirements of Article 13 of China's Arbitration Law? ${ }^{26}$

China's arbitration institutions also have undertaken major efforts in the context of BRI. For instance, the Wuhan Arbitration Commission is the first to set up the China One Belt One Road Arbitration Court, which is dedicated to resolving relevant disputes arising from the BRI, to protecting the legitimate rights and interests of involved parties, and to ensuring the smooth progress of overseas projects. ${ }^{27}$

25 Zhuhai Arbitration Commission, Ad Hoc Arbitration Rules 2017.

26 China's Arbitration Law, art 13. It stipulates that, 'An arbitration commission shall appoint its arbitrators from among righteous and upright persons. An arbitrator shall meet one of the conditions set forth below: (1) He or she has passed the national uniform legal profession qualification examination and obtained the legal profession qualification, and conducted the arbitration work for eight years or more; (2) To have worked as a lawyer for at least eight years; (3) He or she has served as a judge for eight years or more; (4) To have been engaged in legal research or legal education, possessing a senior professional title; or (5) To have acquired the knowledge of law, engaged in the professional work in the field of economy and trade, etc., possessing a senior professional title or having an equivalent professional level'.

27 Pan, 20 December 2017. 
Another outstanding example is the Beijing Arbitration Commission (BAC), which focuses itself on becoming a transnational arbitration center. BAC's active appearance on the international stage has greatly boosted its profile, attracted significant attention from the international arbitration community and led to more and more co-operation relationships with international/ foreign arbitration institutions. For instance, together with Shanghai International Arbitration Center (SHIAC) and Shenzhen Court of International Arbitration (SCIA), BAC jointly established the China-Africa Joint Arbitration Center (CAJAC) with Nairobi and South-African arbitration institutions, which aims to streamline the dispute resolution mechanism between China and Africa. ${ }^{28}$ BAC has also signed the Belt and Road Arbitration Initiative Cooperation Agreement together with Kuala Lumpur and Cairo arbitration institutions. ${ }^{29}$

Furthermore, Chinese leading arbitration institutions have been quite diligent upgrading their institutional rules and taking innovative measures to maintain their competitive edge in China, and further boost their images in the international arbitration market.

In this respect, China International Economic and Trade Arbitration Commission (CIETAC), the eldest Chinese arbitration institution with early privileges to administer foreign-related disputes, which still administers cases with the highest annual amount in disputes today, has taken noticeable measures to keep its leading role. This has included, for example, promulgating the 'CIETAC International Investment Arbitration Rules' 30 in September 2017 in order to take on investment arbitrations. The Rules expressly recognize third-party funding and introduce public hearing of investment arbitration cases. The CIETAC Mediation Center was also introduced in May 2018.

In the meantime, Shenzhen Court of International Arbitration (SCIA) has also been proactive in improving its arbitration rules to gain the shares and boost its profile in the competitive market. On December 23rd, 2018, the SCIA promulgated the 'Arbitration Rules of SCIA (2019 version), ${ }^{31}$ which for the first time in China creatively establishes an optional repeat arbitration procedure, in order to meet the actual needs of parties who would like to have a second opportunity to arbitrate their substantive issues within the arbitral proceedings. This innovative option may run against the value of efficiency, an inherent feature arbitration, but indeed, it could meet some parties' desire for ultimate justice, especially those who have extremely high stakes in the disputes.

28 Habib, 26 November 2018.

29 Beijing Arbitration Commission, 9 May 2017.

30 CIETAC, International Investment Arbitration Rules 2017.

31 SCIA, Arbitration Rules 2019. The Rules is not publicly available as of this Article. 
Of all the national judicial efforts devoted to the promotion and construction of China's BRI, the creation and establishment of the CICC by the SPC to hear international commercial disputes is undoubtedly a milestone achievement that will eventually upgrade and integrate China's dispute resolution mechanisms for international commercial disputes.

\subsection{Establishment and Materialization of the cICc}

The idea of the CICC was first conceived in January 2018 with the 'Opinion regarding Establishing One Belt One Road International Commercial Dispute Resolution Mechanism and Institution' (the Opinion). The Opinion set forth three guidelines, (i) the SPC will establish the international commercial court; (ii) the SPC will lead the constitution of an expert committee of international commercial matters; and (iii) a diversified dispute resolution mechanism shall be established which effectively connects litigation, arbitration and mediation, and forms a one-stop dispute resolution center that is convenient, efficient and cost-effective for users. The Opinion further stressed that the international commercial court to be established shall not only strive to achieve the goals of justice, high efficiency, convenience, but also must respect the principle of party autonomy and achieve a diversified and integral dispute resolution mechanism.

In response to the Opinion and on 29 June 2018, the SPC promulgated the 'Provisions of the Supreme People's Court on Several Issues Regarding the Establishment of the International Commercial Court'32 (the CICC Provisions), which essentially codifies the general guidelines and requirements of the Opinion.

On the same date of issuance of the CICC Provisions, the SPC unveiled the First International Commercial Court and the Second International Commercial Court in Shenzhen and Xi'an, respectively, and announced appointment of the first batch of eight judges from the SPC to serve as judges of the CICC. All eight judges selected were judges of the SPC working in the chambers specialized for handling international commercial disputes. By the end of 2018, the CICC in Shenzhen and Xi'an have accepted around 17 cases, ${ }^{33}$ and another seven judges have been appointed to the panel list. ${ }^{34}$

32 SPC, The CICC Provisions 2018.

33 CICC, 'Acceptance of Cases', 29 December 2018.

34 CICC, 'Appointment of Judges', 7 December 2018. 
On August 24th, 2018, the SPC announced the establishment of an International Commercial Expert Committee (the ICEC), with some 32 Chinese and foreign experts selected by the SPC for their expertise in international commercial arbitration, international investment arbitration, international construction projects, international trade, and so forth. ${ }^{35}$ Indeed, the idea of the ICEC and its broad selection of experts from countries along the Belt and Road, with varying legal background, geographical locations, fields of practice, and so forth, all reflect the intended diversity, neutrality and professionalism of the CICC.

Pursuant to the CICC Provisions and the 'Working Rules of the International Commercial Expert Committee (Trial)' (the Working Rules of the ICEC), ${ }^{36}$ the ICEC could, among others competences, (i) conduct mediation between the parties per the entrustment of the CICC and based on the parties' consent, with the fees borne by the parties upon consultation or equally, ${ }^{37}$ (ii) help explain or clarify rules of international commercial transactions, and provide expert opinion on the content and application of foreign laws, ${ }^{38}$ and (iii) advise on issues relating to the development plan of the CICC, and comment on the SPC's contemplated judicial interpretations and/or policies.

After the CICC's establishment, the SPC proceeded to explore and issue implementation rules relating to the operation of the cicc. Quite efficiently, the SPC issued on 5 December 2018, (i) the 'Notice of the SPC on Inclusion of the First Group of International Commercial Arbitration and Mediation Institutions in the 'One-stop' Diversified International Commercial Dispute Resolution Mechanism' (the Notice on Institutions Inclusion), which selected and included seven Chinese arbitration institutions and mediation arbitrations ${ }^{39}$ into the featured one-stop dispute solution platform; (ii) the 'Procedural Rules of China's International Commercial Courts (Trial)' (the Procedural Rules of the CICC) and (iii) Working Rules of the ICEC, affording clarity and guidance on the conduct of the CICC including its expert committee, the ICEC.

35 CICC, Decision on Appointing Experts 2018.

36 SPC, The Working Rules of the ICEC 2018.

37 CICC, Procedural Rules 2018, art 37.

38 SPC, The CICC Provisions 2018, arts 8(4) and 12; see also, ibid, art 31.

39 China International Economic and Trade Arbitration Commission (CIETAC); Shanghai International Economic and Trade Arbitration Commission, also known as Shanghai International Arbitration Center (SHIAC); Shenzhen Court of International Arbitration (SCIA); Beijing Arbitration Commission (BAC); China Maritime Arbitration Commission (CMAC); China Council for the Promotion of International Trade (CCPIT) Mediation Center; Shanghai Commercial Mediation Center (sCMC). 


\subsection{Innovative Aspects of the cIcc}

The CICC is possessed of certain innovative aspects, concerning (i) finality, (ii) working language, (iii) rules of evidence and (iv) the role of international experts, which are now examined, below.

\subsubsection{Finality}

Pursuant to Article 15 of the CICC Provisions, ${ }^{40}$ the judgments and rulings made by the CICC are final and binding on the parties, similar to arbitral awards but different from judicial judgments rendered under traditional twoinstance court procedures. It is to be noted, that finality of the CICC judgments does not preclude a party from seeking retrial with the $\mathrm{SPC},{ }^{41}$ which is an available remedy for normal litigation cases, although retrial is granted under very rare circumstances at the SPC's discretion.

The SPC, when acting as the court hearing the first-instance civil cases, issues judgments and rulings that are final and cannot be appealed, ${ }^{42}$ which is an exception to the two-instance court procedures. Some scholars comment that such a system design seems to deprive the parties of the right of appeal, and rather prejudices interests thereby. Moreover, since it is a case under the jurisdiction of the SPC, naturally it is believed that the stakes of the case would inevitably be significant, hence even greater importance of the appellate interest. Others further propose establishing specialized commercial courts at the level of Intermediate People's Courts or Provincial Higher People's Courts, where the SPC would serve as the appeal court, or alternatively, setting up a first trial tribunal and final tribunal within the SPC, which would be more in line with the jurisdictional provisions and spirit of the 'Civil Procedure Law of People's Republic of China' (the CPL). ${ }^{43}$

By contrast, it seems a prevailing trend for international commercial courts to afford appeal procedures, which are available, for example, with the Singapore International Commercial Court (sICC), the Abu Dhabi Global Markets

40 SPC, The CICC Provisions 2018, art 15. It stipulates that, 'Judgments and verdicts issued by international commercial courts are legally effective judgments and verdicts'.

41 Ibid, art 16. It stipulates that, 'Parties may, in accordance with the provisions of the Civil Procedure Law, apply to the main body of the Supreme People's Court for a retrial of a legally effective judgment, ruling or conciliation statement made by the International Commercial Court'.

42 China Civil Procedure Law. art 155. It stipulates that, 'The judgments and rulings of the Supreme People's Court and the judgments and rulings not appealable in accordance with law or not appealed during the prescribed time limit shall be effective judgments and rulings'.

Y Shen, 2 July 2018. 
Courts (ADGM Courts), the Astana International Financial Centre Court (AIFC Court), and the Dubai International Financial Centre Courts (DIFC Courts). Commentators suggested that the cicc could also afford an appeal mechanism while in the meantime, avail the parties of an opt-out option to waive the right to appeal, so as to achieve a balance between efficiency and protection of parties' right to appeal. ${ }^{44}$

\subsubsection{Language to be used}

Proficient use of English as the working language is also required for the selection of judges for the CICC. ${ }^{45} \mathrm{On}$ such basis, the CICC can accept documentary evidence in English without Chinese translation when the parties so agree, ${ }^{46}$ which is a breakthrough to the general requirement in Chinese litigation for certified Chinese translation of documents originally in a foreign language. This relaxed requirement concerning language should reduce the burden of the parties and achieve efficiency and lower costs of the proceedings.

However, neither the CICC Provisions nor the Procedural Rules of the CICC allow the judges to use English in the hearing of a case. This is because Article 262 of the CPL stipulates that a Chinese court shall use the spoken and written languages of the People's Republic of China when trying foreign-related civil cases. No breakthrough is made here.

Comparatively, the SICC uses English as the main language of trial. Even in non-English speaking countries, both the Dubai International Financial Centre Courts (DIFC Courts) and the Abu Dhabi Global Markets Courts (ADGM Courts), ${ }^{47}$ for example, use English as the working language for hearing cases. In addition, in the wave of international commercial court start-ups emerging recently, countries including Germany, France, and Belgium, whose official

$44 \quad$ Li, 2 July 2018.

45 SPC, The CICC Provisions 2018, art 4. It stipulates that, 'Judges of the International Commercial Court shall be selected and appointed by the Supreme People's Court from the senior judges who are experienced in trial work, familiar with international treaties, international usages, and international trade and investment practices, and capable of using Chinese and English proficiently as working languages'.

46 Ibid, art 9. It stipulates that, 'When parties submit the evidentiary materials to the International Commercial Court that came into being outside the territory of the People's Republic of China, regardless of whether they have been notarized, authenticated or otherwise formally certified, they shall be cross-examined during the court hearing. In case the evidentiary materials submitted by a party is in English, a Chinese translation may not be accompanied upon the opposing party's consent'.

47 Dubai International Financial Centre Courts (DIFC Courts) <https://www.difccourts. ae/> accessed 25 January 2019; and the Abu Dhabi Global Markets Courts (ADGM Courts) <https://www.adgm.com/doing-business/adgm-courts/home/> accessed 25January 2019. 
languages are not English, have begun to establish or already streamlined their international commercial courts with English as their main working language. ${ }^{48}$

\subsubsection{Relaxed Rules on Evidence Formality and Submissions}

Much more relaxed, compared with normal Chinese judicial proceedings, is when the CICC hears cases, notarization and certification of extraterritorial evidence are not necessary. Extraterritorial evidence that has not been notarized and certified may be used as evidence as long as it is cross-examined and the authenticity, relevance and legitimacy of the evidence are recognized. ${ }^{49}$

Besides that, contrary to traditional paper-based submission, the parties in the cICC proceedings could file their submissions through an electronic litigation platform on the CICC's official website (cicc.court.gov.cn), and could also adopt other means of submission such as e-mail, mailing, submitting on site, and further ways permitted by the cicc. ${ }^{50}$ These innovative measures echo the construction of a 'Smart Court', forms a convenient, expeditious and cost-efficient one-stop diversified international commercial dispute resolution mechanism.

\subsubsection{International Commercial Expert Committee}

Another innovative move is the establishment of the ICEC, as mentioned at the beginning of this section. The ICEC is expected to play a credible and professional role in achieving efficient, low-cost and convenient resolution of international commercial disputes, and further bring resolving disputes in China in line with prevailing international practices.

\section{5}

\section{Conclusion}

The aforementioned innovations taken by China's government, its highest level of judiciary the SPC, as well as the Chinese arbitration institutions, are all for the good intention of building China into a more friendly seat for resolving international commercial disputes. However, they are not free from problems.

Taking the cICc for example, it is notably regarded as a milestone in the development of international commercial dispute resolution mechanisms. Institutional innovations have been made as of today, yet many specific issues

$48 \quad$ Liao, 27 February 2018.

49 SPC, The CiCC Provisions 2018, art 9.

50 CICC, Procedural Rules 2018, art5. 
are still in need of clarification and guidance in the actual operation of the CICC system. In particular, with respect to the one-stop solution platform that it affords to Chinese and international users, for instance, whether to adopt a two-instance court procedure that could be opted-out by the parties? Whether to introduce international judges and allow English as an optional language for hearing? Also, similar to the approach taken by the sICC and DIFC Courts, whether to consider signing more bilateral memorandum of judicial cooperation with other jurisdictions for the bilateral/multilateral recognition and enforcement of court judgments and decisions before China's final approval of the Hague Convention on Choice of Court Agreements. ${ }^{51}$ The answers to such questions await decision.

\section{Reference List}

[2013] Hu yi zhong min ren (waizhong) zi No.2. (2013) 沪一中民认（外仲）字第 2 号.

Arbitration Law of the People's Republic of China (2017 Amendment) (promulgated on 1 September 2017, effective from 1 January 2018) <www.npc.gov.cn/npc/ xinwen/2017-09/12/content_2028692.htm > accessed 25 January 2019 .

Beijing Attribution Commission, 'In-Depth Exploration of the Arbitral Institution Linkage Mechanism to Jointly Build the "Belt and Road" Arbitration Building' (Chinagoabroad 9 May 2017) <www.chinagoabroad.com/zh/member_update/23760> accessed 25 January 2019.

Beijing Higher People's Court, Opinions of the Beijing Higher People's Court on Several Issues Concerning the Trial of Requesting the Determination of the Validity of an Arbitration Agreement and the Application for Cancellation of an Arbitral Award (promulgated on 2 December 1999) <www.chinalawedu.com/falvfagui/ fg23079/39003.shtml $>$ accessed 25 January 2019.

China International Commercial Court, 'CICC Has Accepted a Number of International Commercial Dispute Cases' (CICC, 29 December 2018) <http://cicc.court.gov.cn/ $\mathrm{html} / 1 / 218 / 149 / 192 / 1150 . h t m l>$ accessed 25 January 2019.

China International Commercial Court, Decision of the SPC on Appointing the First Batch of Experts of ICEC (CICC, 24 August 2018) <http://cicc.court.gov.cn/ html/1/218/149/192/949.html $>$ accessed 25 January 2019.

$51 \quad$ The main problem is that only 29 countries have joined the Hague Convention on Choice of Court Agreements, which is even less than $20 \%$ of the signed countries of the New York Convention. If the court judgments of many countries along the 'Belt and Road' cannot be enforced between the countries, then the judiciary will be greatly restricted. 
China International Commercial Court, 'The SPC Appointed the Second Patch of Judges of CICC' (CICC, 7 December 2018) <http://cicc.court.gov.cn/html/1/ 218/149/192/1130.html > accessed 25 January 2019.

CIETAC, CIETAC International Investment Arbitration Rules (promulgated on 12 September 2017, effective from 1 October 2017) <www.cietac.org.cn/index.php?m $=$ Page $\& \mathrm{a}=$ index $\& \mathrm{id}=390 \& \mathrm{l}=\mathrm{en}>$ accessed 25 January 2019 .

Civil Procedure Law (2017 Amendment) (promulgated on 27 June 2017, effective form 1 July 2017) <www.npc.gov.cn/npc/xinwen/2017-06/29/content_2024892.htm> accessed 25 January 2019.

Fan K, 'Arbitration in China: Practice, Legal Obstacles, and Reforms' (2008) 19 ICC International Court of Arbitration Bulletin 25.

Habib S, 'Interview with Deline Beukes, CEO of the China Africa Joint Arbitration Centre Johannesburg' (Kluwer Arbitration Blog, 26 November 2018) <www.cietac-sh. org/SHIAC/arbitrate_informations_detail.aspx?id=283> accessed 25 January 2019.

He J, 'Leveraging the BRI China should Raise the Right to Speak in Resolving International Commercial Disputes' The 21st Century Business Herald (Beijing, 19 September 2016) <finance.sina.com.cn/roll/2016-09-19/doc-ifxvykwk5111345.shtml> accessed 25 January 2019.

Jiangsu Higher People's Court, Opinions on Several Issues Concerning the Trial of Judicial Review of Civil and Commercial Arbitration Cases (promulgated on 6 September 2010) <www.66law.cn/domainblog/73431.aspx > accessed 25 January 2019.

Lau R, 'China's Belt and Road: What's in it for Malaysia?' Borneo Post(Borneo, 3 September 2017) <www.theborneopost.com/2017/og/o3/chinas-belt-and-road-whatsin-it-for-malaysia/> accessed 25 January 2019.

Li Y, 'China Set Up CICC for the First Time' China Business News (Beijing, 2 July 2018) <http://finance.eastmoney.com/news/1365,20180630897927384.html> accessed 25 January 2019.

Liao Y, 'Latest Development and Enlightenment of the Establishment of Extraterritorial International Commercial Court' (CCPIT, 27 February 2018) <www.ccpit.org/ Contents/Channel_4132/2018/0223/967389/content_967389.htm > accessed 25January 2019.

Liu Y and Lin S, 'Drawing on the UNCITRAL Model Law on International Commercial Arbitration to Improve China's Arbitration Law' (2018) 17 Journal of Taiyuan Normal University 78.

Pan X, “One Belt and One Road" (China) Arbitration Institute PPP Arbitration Center was Established' China Economic Herald (Beijing, 20 December 2017) <www.h2ochina.com/news/268232.html> accessed 25 January 2019.

Prusinowska M, 'China as a Global Arbitration Player? Recent Developments of Chinese Arbitration System and Directions for Further Changes' (2017) 10 Tsinghua China Law Review 33. 
SCIA, Arbitration Rules of SCIA (2019 version) (promulgated on 23 December 2018, effective from 21 February 2019).

Shen H, 'Concentrate the Wisdom of Chinese and Foreign Experts to Help Build International Commercial Dispute Settlement Mechanism' People's Court Daily (Beijing, 21 November 2018) 7.

Shen Y, 'The Establishment of CICC and the New Development of China's Dispute Settlement Mechanism' (TianYuanLawFirm, 2 July 2018) <mp.weixin.qq.com/ s/7WZyeINhPrFZcut R5RutaA > accessed 25 January 2019.

The Supreme People's Court of the PRC, Interpretations of the Supreme People's Court on Several Issues concerning Application of the Law of the People's Republic of China on Choice of Law for Foreign-Related Civil Relationships (promulgated on 28 December 2012, effective from 7 January 2013) <www.chinacourt.org/law/ detail/2012/12/id/146055.shtml $>$ accessed 25 January 2019.

The Supreme People's Court of the PRC, Notice concerning Certain Issues regarding Centralized Administration of Judicial Review of Arbitration Cases (promulgated on 22 May 2017) <https://baijiahao.baidu.com/s?id=1584640451021295097\&wfr =spider\&for=pc $>$ accessed 25 January 2019.

The Supreme People's Court of the PRC, Procedural Rules of China International Commercial Courts (Trial) (effective from 5 December 2018) <http://cicc.court.gov.cn/ html/1/218/149/192/1122.html $>$ accessed 25 January 2019.

The Supreme People's Court of the PRC, Provisions of the SPC on Application for Approval of Arbitration Cases that are Subject to Judicial Review (promulgated on 26 December 2017, effective from 1 January 2018) <www.court.gov.cn/fabuxiangqing-75862.html > accessed 25 January 2019.

The Supreme People's Court of the PRC, Provisions of the SPC on Certain Issues related to the Conduct of Judicial Review of Arbitration Cases (promulgated on 26 December 2017, effective from 1 January 2018) <www.court.gov.cn/fabu-xiangqing-75872 .html> accessed 25 January 2019.

The Supreme People's Court of the PRC, Provisions of the Supreme People's Court on Several Issues Regarding the Establishment of the International Commercial Court (promulgated on 29 June 2018, effective from 1 July 2018) < http://cicc.court.gov.cn/ html/1/219/199/201/817.html> accessed 25 January 2019.

The Supreme People's Court of the PRC, Provisions on Certain Issues relating to People's Courts' Handling of Enforcement Cases of Arbitral Awards (promulgated on 22 February 2018, effective from 1 March 2018) <https://baijiahao.baidu.com/s?id $=1593169927748877421 \& w f r=$ spider $\&$ for $=$ pc $>$ accessed 25 January 2019.

The Supreme People's Court of the PRC, SPC's Opinions on Providing Judicial Safeguards for the Construction of Pilot Free Trade Zones (promulgated on 30 Dec. 2016) < www.court.gov.cn/zixun-xiangqing-34502.html> accessed 25 January 2019. 
The Supreme People's Court of the PRC, Working Rules of the International Commercial Expert Committee of the Supreme People's Court (Trial) (effective from 5 December 2018) <http://cicc.court.gov.cn/html/1/218/149/192/1126.html> accessed 25 January 2019.

Tang X, "The Determination of Foreign-Related Factors in the Arbitration involving China's FTZs' (2017) 12 International Economic and Trade Exploration.

The New York Convention (adopted on 10 June 1958, effective from 7 June 1959) UNTS 4739 .

Wang S and Hilmer S E, 'China Arbitration Law v UNCITRAL Model Law' (2006) 6 International Arbitration Law Review 1.

Zhuhai Arbitration Commission, The Ad Hoc Arbitration Rules of the Hengqin Free Trade Zone (promulgated on 23 March 2017, effective from 15 April 2017) <www .zhac.org.cn/zcgzall/html/?528.html> accessed 25 January 2019. 